\title{
A new Theory of Geysers
}

This content has been downloaded from IOPscience. Please scroll down to see the full text. 1897 Proc. Phys. Soc. London 1663

(http://iopscience.iop.org/1478-7814/16/1/314)

View the table of contents for this issue, or go to the journal homepage for more

Download details:

IP Address: 137.149.200.5

This content was downloaded on 01/10/2015 at 12:03

Please note that terms and conditions apply. 
the sea-horizon, and the instant when it is eclipsed by the shadow of night.

The author calls attention to a phenomenon hitherto unnoticed, i. e., that the heated air ascending from the Peak casts a shadow, seen as a faint prolongation of that of the Peak, rising obliquely from its apex. A photograph was exhibited, taken on a quarter-plate, in which is visible the curvature of the horizon as viewed from the altitude of the Peak.

An interesting series of photographs, illustrating the conformation of the Peak and the phenoment of sunrise and twilight in that latitude, was also shown. In regard to twilight, it is noticed that the first approach of night, as observed looking eastward, is marked by a dark border of about five degrees width, followed by a sky somewhat lighter.

\section{A new Theory of Geysers. By Rev. T. C. Porter, M.A.*}

\section{[Abstract.]}

THe theories of Bunsen and others fail to explain why the geyser throat appears almost completely full at the end of an eruption. This immediate re-filling is the more remarkable when it is remembered that some of the geysers of the Yellowstone region discharge a million and a half gallons at each eruption, and that the eruptions may occur at fiveminute intervals. Moreover, the theories generally accepted assume steeper temperature-gradients than those in a region like Yellowstone. The author suggests that the phenomena are better explained on the assumption of an arrangement of strata such as exists in artesian-well districts; the throat or shaft of the geyser being in the position of a well communicating with a subterranean stream-the "tube" of the geyser. From the disturbed nature of the region, the tube of the geyser probably follows a waved course. The "shaft"

* Read February 26, 1898. 
rises from the crest of the terminal wave; the other crests may act as steam-traps. Since a basin-like formation is characteristic of all geyser regions, it is fair to assume that the end of the tube remote from the shaft has an outcrop in the hills that form the sides of the basin. By means of this outcrop, water continually flows into the tube. Where the tube does not sink deeply enough to attain the temperatnre necessary for the generation of steam, a quietly-flowing hot spring is the result. But if at any point the tube descends to underground temperatures sufficiently great, steam is formed, and is trapped at the highest point of a bend. Ultimately this steam checks the flow of water, until the accumulated head of cool water from the hills overcomes the resistance, condenses the steam, and re-establishes liquid continuity. Urged by the pressure hebind it, the steam is impelled towards the geyser throat; it forces the hot water before it until equilibrium is once again restored in the tube.

\section{A Method of Viewing Lantern Projections in Stereo- scopic Relief. By Rev. T. C. Porter, M.A.*}

\section{[Abstract.]}

A sLotTed disc rotates in front of two lanterns. These project two stereoscopic views in rapid alternation upon a screen in such a way that the two projections are approximately superposed. In the rim of the disc other slots are cut, through which the observer looks. The arrangement of slots is such that the right or left eye is only able to see the screen at the moment when its own picture, i.e., the picture from the right or left lantern, is on the screen. When the rotation is sufficiently rapid, the views appear as one, without "flicker," in stereoscopic relief.

* Read February 26, 1808. 